\title{
Rural Areas Are More Vulnerable To Covid-19: Preventative Measures To Curb Infection
}

\section{PR Risenga}

Department of Health Studies, University of South Africa.

Corresponding author: PR Risenga, Department of Health Studies, University of South Africa.

Received date: May 03, 2020; Accepted date: May 13, 2020; Published date: May 18,2020

Citation: PR Risenga, (2020) Rural Areas Are More Vulnerable To Covid-19: Preventative Measures To Curb Infection. J Clinical Research and Reports, 4(3); DOI:10.31579/2690-1919/090

Copyright: () 2020 PR Risenga, This is an open access article distributed under the Creative Commons Attribution License, which permits unrestricted use, distribution, and reproduction in any medium, provided the original work is properly cited

\section{Abstract}

South Africa like any other country globally is faced with the covid-19 pandemic. The virus has affected all the provinces differently. However, it's still early to speculate though the badly hit provinces include Gauteng and Western Cape. Gauteng consists of different racial groups from all the other provinces residing there while in their respective employment areas. The same group of people in Gauteng travel to their respective places of origin mostly month end. These activities make other provinces vulnerable to covid-19 from the mostly affected province. The challenging part is that the people in the rural areas are more likely to be less knowledgeable when it comes to the covid-19 pandemic (CDC,2020). The people in rural areas have little opportunity to learn of the virus, understand the risks and gain knowledge on prevention as well as recovery. There is currently no vaccine to prevent coronavirus disease 2019 (COVID-19). The purpose of the study was to assess the best practices used by other community members regarding application of the general principles outlined for preventing the spread of covid-19 in rural areas. The objectives were to explore and describe best practices used by other community members in preventing the spread of covid-19 in rural areas. Five steps of systemic review were used to get relevant information in the best practices from framing of question for review, identifying relevant work, assessing the quality of studies, summarizing the evidence and interpreting the finding. The review in prevention of covid-19 yielded specific measures that can be useful in rural communities.

Key Words: Covid-19; Preventative Measures

\section{Conclusion}

The best way to prevent illness is to avoid being exposed to this virus. People in rural areas need to be equipped to control the spread of covid19.

After thorough reading of different studies and reports the information has been grouped into four key areas for prevention of the spread of covid19 as presented below which might be helpful in the rural communities of South Africa.

\section{Affordable hand washing and hand sanitisers in rural areas}

To address the covid-19 pandemic it is important to ensure that all the people understand it and apply principles related to prevention of the spread of the infection. The Centers for Disease Control and Prevention (CDC , 2019) outline instructions to make sure that people do not spread the virus, however, this should be adapted according the conditions where people find themselves. Instructions outlined include hand washing, covering mouth and nose when going in public, and keeping social distance. Washing hands might pose a challenge due to scarcity of the water in rural areas.
A study conducted in India indicated that a single 20-second wash plus wetting and rinsing uses at least two litres of water, more than half a gallon. This confirms challenges experienced by rural communities around the world. Different studies conducted in many rural areas indicated that rural areas having water challenges and hand washing is a problem. However communities had adopted the use of a new technology called tippy tap and was found to be effective for public use in area where there are water shortages. Handwashing was made easy by ensuring that all community members were trained. The Tippy Tap is a hands-free device for hand washing that is especially designed for rural areas where there is no running water. It is operated by a foot lever and thus reduces the chance for the transmission of pathogens as the user only touches a bar of soap suspended by a string. CDC (2019) has developed steps regarding making of tippy tap which is accessible to the public use. Different countries in Africa such Kenya, Ghana and Zimbabwe have used the method successfully. Home made hand saniters were prepared by adding 4 teaspoons of jik in four cups of water into a spray bottle and used as hand saniters. However they were also advised to avoid touching eyes, nose, and mouth with unwashed hands. And this reflect how critical washing of hands in prevention of covid-19.

\section{Good cleaning solutions made easy for infection control}


It has been discovered that covid-19 was also discovered in toilet seats and other hard places so with people in rural areas sharing toilets. CDC (2019) has indicated that the following measures can be useful in communities: The cleaning disinfectant can be prepared by mixing water with bleach for cleaning purposes by adding 5 tablespoons of jik to four liters of water. The information revealed that unexpired household bleach has been found to be effective against coronaviruses when properly diluted. Communities were also advised that when cleaning they need to ensure a contact time of at least 1 minute and allowing proper ventilation during and after application on tables, doorknobs, light switches, countertops, handles, desks, phones, toilets and sinks. However, toilets should always be cleaned between use to kill the viruses including covid19 (WHO, 2020). Rural areas in South Africa can also benefit from this information because it cost less to do it and yet at the same time prevent the spread of covid-19 as they share places like the toilets.

\section{Feasibility of mask usage and coughing etiquette in rural areas}

Centers for Disease Control and Prevention (CDC, 2020) advises everyone to wear face masks in public, even for those who don't display symptoms or know of exposure to an infected person. Everyone should wear a cloth face cover when they must go out in public. Cloth face coverings should not be placed on young children under age 2, anyone who has trouble breathing, or is unconscious, incapacitated or otherwise unable to remove the mask without assistance. The cloth face cover is meant to protect other people in case the person is infected. The face cloth mask can be created by own mask using an old cloth, it to fit different members of household including children above the age of 2 years. Correct measurement of the face is key to ensure that it fits snuggly. When taking it off avoid touching the outer part as it might be contaminated. Community members should be advised to avoid sharing the face cloth, wash it daily and iron before use. These are the measures which can be communicated to members of the public in rural areas to address covid19 pandemic and they been seen to be beneficial in other countries. Coughing ettiquette has also been introduced in rural areas and people we taught how can they apply it by always covering the mouth and nose with a tissue when one is coughing or sneezing or use the inside of the elbow. Throwing of used tissues in the trash in the pit used in rural communities for refuse disposal need to be emphasized to avoid the spread of covid-19 and to wash hands after coughing or sneezing (Khan, \& Sinha, 2020; WHO, 2020). Using these best practices might help in preventing the spread of covid-19 in South Africa.

\section{Social distance another key measure in covid-19}

It is has been reported that COVID-19 spreads mainly among people who are in close contact for a prolonged period (CDC 2020). The coronavirus spread mainly happens when an infected person coughs, sneezes, or talks, and droplets from their mouth or nose are launched into the air and land in the mouths or noses of people nearby. The droplets can also be inhaled into the lungs. Recent studies indicate that people who are infected but do not have symptoms likely also play a role in the spread of COVID-19.

The other part which plays part in the spread of infection happens when a person touches a surface or object that has the virus on it and then touching their own mouth, nose, or eyes. Thus social distancing remains the key point in limiting contact with infected people and contaminated surfaces.

Although the risk of severe illness may be different for everyone, anyone can get and spread COVID-19. Everyone has a role to play in slowing the spread and protecting themselves, their family, and their community. However, social distancing might pose a challenge in rural and in low income countries more specifically during grant days, because majority of the people rely in government grant to survive. Do we have other measures to address these challenges? More studies should be conducted to address this challenge.

\section{Conclusion}

Monnat (2020) indicated that transmission rates may be lower in rural areas of America because they are densely populated, and this is the opposite of what is happening in some rural communities of South Africa, where people are overpopulated due to extended families. Hence addressing their challenges could help in curbing the spread of the virus.

\section{References}

1. CDC (2019) Novel coronavirus, Wuhan, China. 2020.

2. Coronavirus disease (COVID-19) advice for the public. Geneva: World Health Organization; 2020. Continuum Codes for U.S. Counties.

3. Coronavirus disease 2019 (COVID-19) Situation Report - 73.

4. Home care for patients with suspected novel coronavirus (COVID-19) infection presenting with mild symptoms, and management of their contacts: interim guidance, 5 April 2020.)

5. Infection prevention and control during health care when novel coronavirus ( $\mathrm{nCoV}$ ) infection is suspected: interim guidance, 19 March 2020. Geneva: World Health Organization.

6. Khan, D.M.S \& Sinha, S. 2020. Coronavirus OP-ED: Covid-19 droplets and aerosol transmission: how do we protect ourselves and others?

7. National Health Commission of People's Republic of China. Prevent guideline of 2019-nCoV. 2020.

8. Shannon Monnat, 24 Mar 24, 2020 Research Update: Why Coronavirus Could Hit Rural Areas Harder: Daily Yonder. USA. Accessed 16 April 2020

9. WHO. Novel Coronavirus-China. 2020.. Accessed 2 April 2020. 
10. World Health Organization. Infection prevention and control during health care when COVID-19 is suspected: interim guidance, (accessed 29 March 2020).

CC) This work is licensed under Creative Commons Attribution 4.0 License

To Submit Your Article Click Here: Submit Article

DOI:10.31579/2690-1919/090
Ready to submit your research? Choose Auctores and benefit from:

* fast, convenient online submission

* rigorous peer review by experienced research in your field

* rapid publication on acceptance

* authors retain copyrights

* unique DOI for all articles

* immediate, unrestricted online access

At Auctores, research is always in progress.

Learn more https://www.auctoresonline.org/journals/journal-of-clinicalresearch-and-reports 